\title{
E-Book versus Printed Materials: Preferences of University Students*
}

\author{
Gonca Cumaoglu, Esra Sacici, \& Kerem Torun \\ Yeditepe University, Turkey
}

\begin{abstract}
Reading habits, accessing resources, and material preferences change rapidly in a digital world. University students, as digital natives, are accessing countless resources, from lecture notes to research papers electronically. The change of reading habits with a great scale has led to differentiation on accessibility of resources, archiving them and usage of related technologies. The purpose of this study is to examine the e-book usage preferences versus printed material along with reading habits in a context of different variables. Additionally, different uses of e-books in a variety of faculties have been the focus of this study. The participants comprised of 222 students, studying in 36 different universities across Turkey. A questionnaire was developed specifically for the study. The questionnaire consisted of three parts: Printed book reading habits, e-book reading habits (methods of reaching e-books, aim of usage etc.), and technological knowledge (e-book related tools and file formats etc.). According to the results of study, approximately $68 \%$ of university students stated that they read one book in a week and $62 \%$ indicated that they are e-book readers. Moreover, there was a significant relationship between social environment and reading habits of students. University students put forward accessibility advantage (68\%) of e-book and stated that they mostly read e-book for research (81\%). E-book format which is most commonly preferred among students is Portable Document Format (pdf) $(73 \%)$, while the computer is the most commonly used e-book medium (60\%).
\end{abstract}

Keywords: E-book; Printed material; Reading preferences; Reading habits; University students; Higher education

\section{Introduction}

In this age we witness that the printed resources have been replaced with electronic resources and the habits related to newspaper, magazine, course material and book reading have undergone changes. Amongst modern-age college students in particular who were born as digital-natives to the $21^{\text {st }}$ century, these habits demonstrate even further variance. One of the most noteworthy concepts that emerged within this context has been e-book. A common definition of e-book was suggested by Armstrong, Edwards, and Lonsdale (2002) as: [...] any piece of electronic text regardless of size or composition (a digital object), but excluding journal publications, made

\footnotetext{
* A brief version of this paper was presented at the International Conference on Communication, Media, and Technology (ICCMT'12)
} 
available electronically (or optically) for any device (handheld or desk-bound) that includes a screen.

During the last 10 years e-book releases of publishers, e-book catalogues prepared by university libraries, easy internet access to resources have all together contributed to the spread of e-book use. Despite the fact that reading from a screen appears to be disadvantageous at first sight, the counter-part advantages such as mobility, saving physical space, convenience, saving time and money, ease-of-use are the primary motivations in preferring e-books (Rosso, 2009). The effect of this transformation from printed material to e-books on our reading habits is also a subject worthy of deeper analysis. The purpose of this study is to analyze the variables relevant with the e-book reading habits of university students (the aspects they deem advantageous, related purposes, methods of access, the most frequently used e-book environment and file formats).

Although the reading electronic documents in digital environment are commonly associated with e-book, it would be beneficial to study this concept along with its software and hardware related aspects. From hardware aspect, the tablets were specifically designed and manufactured for reading e-books along with computers. (eg. Kindle.) Such devices have many advantages due to their mobility, ability to store a large number of books, and its convenience for reading anytime anywhere. As for the software aspect, although the manufacturers of such technology developed their own software and file systems for e-book reading, there are also common file types that can be used in each device available (i.e. PDF) Apart from software and hardware, the old books are required to be converted to e-book format as the new books should be published in such format. In this sense, the print houses publishing the books in e-book format and the university libraries compiling e-book catalogues, supported the establishment of an e-book archive and led to the widespread use of e-book. An announcement of a website, which has the largest book sales network on web, stating that the aforementioned site sold 114 e-books against each 100 hardcopies in 2012, is already sufficient to provide us a general idea regarding how widespread the e-book is.

\section{Literature Review}

With electronic books becoming widespread, various studies have begun to be carried out about reading habits, digital catalogs, and e-book device. A vast majority of these studies have focused on university students. This is a foregone conclusion considering that e-books became widespread at first in academic libraries for emergence of electronic journals (Mischo, Norman, Shelburne, \& Schlembach, 2007; Shelburne, 2009). In those studies, the main discussion topics have been the ratio of preference in comparison to printed materials (Nicholas, Rowlands, Clark, Huntington, Jamali, \& Olle', 2008), perceptions related to the advantages of e-books (Cassidy, Martinez, \& Shen, 2012), effect of e-books on learning (Annand, 2008; Muir \& Hawes, 2013; Szapkiw, Courduff, Carter, \& Bennett, 2013), library collections and circulation of e-books in academic libraries versus printed books (Christianson, 2005; Slater, 2009; Sprague \& Hunter, 2009; Vasileiou, Rowley, \& Hartley, 2012). 
In a study examining the e-book usage patterns of university students (Ismail \& Zainab, 2005), use and non-use of e-books are determined by several circumstances in a model. This model has four dimensions that interact with each other; technological competencies, users' own cognitive makeup, the level of access to e-books, and the types of function or use made of the e-books. In the study although about $70 \%$ of the participants rate positively on the e-book service and rate themselves as skilled in Internet use and have positive attitude towards the e-book service, the level of e-book use is low (39\%). The students become aware of the e-book service mainly while visiting the university library website. In a study which demonstrated the ratio of e-book use as 37\% (Letchumanan \& Tarmizi, 2010) it has been detected that use is basically dependent on access and the students who have no previous familiarity with this technology have no tendency to use ebooks either.

As manifested by a large-scale survey in UK with the participation of 120 universities (Nicholas, Rowlands, Clark, Huntington, Jamali, \& Olle', 2008) acceptance of e-book use among students is by the ratio of $62 \%$. In a different large-scale survey $(\mathrm{N}=1547)$ covering the acceptance and use of ebook $57 \%$ of students were found to have used e-books. The remainder of students who provided a negative answer on e-book use has been basically the ones who are not aware of the availability of this service at university library (Shelburne, 2009). The research has also demonstrated that students view easy-access advantage of e-book as its primary benefit. A different research (Zhang \& Beckman, 2011) in support of these surveys ( $N=1450)$ has likewise presented that the use of ebook is rather common with a ratio of $53 \%$ amongst university students. Percentages of e-book usage can be interpreted in different ways in different studies. For example in a study in which the percentage of the non-users of e-books has been $62 \%$, it was concluded that e-books is not preferred to printed material (Cassidy, Martinez, \& Shen, 2012). However in the same study, it was concluded that advantages of electronic style is more valuable though it is not preferred. In this study it was also determined that researchers are not aware of the available electronic resources in the libraries on their own field of study.

Another study (Annand, 2008) probing into the preference of e-books over printed resources and its effect on learning $(\mathrm{N}=109)$ has unraveled that students generally prefer printed materials and as regards learning there is no significant differences between two formats. A different study (Woody, Daniel, \& Baker, 2010) parallel to the findings of previous research has also provided the conclusion that as course material, students prefer printed textbook rather than e-book $(\mathrm{N}=91)$. In another study ( $\mathrm{N}=538)$, grades of university students from a course and perceived learning score were compared according to preference of electronic book or printed resource within the scope of a course. Although there is not a significant difference in the sense of grades as a result of study, perceived learning scores of students who prefer e-book was higher (Szapkiw, Courduff, Carter, \& Bennett, 2013).

Some other studies on e-books investigated circulations of the e-book as a source of libraries. Christianson (2005) studied the .netLibrary usage of five different academic institutions (Louisiana State University, Auburn University, the University of North Texas, Texas A\&M Commerce, and Nunez Community College) in order to grasp the usage patterns of e-book. The overall results of the study showed that the most popular type of e-book circulation amongst those institutions, are on the fields of computers, technology, and specific sciences and the least usage is on the catalogues regarding the fields of social sciences such as history and political sciences. 
Slater (2009) conducted a study in the university library of Oakland University that compared the circulation of e-books between the printed materials and the e-books in the sources of .netLibrary and Safari. One of the most outstanding findings of the study was that while the preferences of the users in the fields of science/technology were leaning towards e-book format, the user preferences on the fields of humanities were in the direction of printed materials.

In a study, conducted in the Library of the University of Idaho (Sprague, Hunter, 2009), e-book related statistics were dissected by focusing three e-book providers; Ebrary, NetLibrary, and Books $24 \times 7$. Although the highest numbers of titles are available in the fields of Business/Economics, Literature and History, when analyzed from the aspect of usage, it was revealed that the most used e-book catalogues are from the subjects of Computer Science, Psychology and Religion. Fewest amount of use was recorded in the field of political sciences. When the library circulations are analyzed, it is obvious that the results of all three separate studies support each other.

\section{Research Questions}

1) What are the book reading frequencies of university students and the types of books read by them?

2) Is there a significant correlation between book reading frequency of university students and book reading habits of their social environment?

3) What are the e-book reading habits of university students?

4) Which e-book medium and file formats are used by university students?

\section{Participants}

\section{Methods}

The participants of this study are comprised of 222 students, studying in 36 different universities across Turkey. While a part of the students filled the questionnaire in a hardcopy edition, the majority accessed the questionnaire online. The questionnaire was announced via an e-mail, sent to the news groups of the universities and the volunteers amongst the students participated. The grade levels and the faculties of 222 participating students ( 131 females and 90 males) are given in Table 1. Although the ages of the participants vary between 18 and28, 60 of them are within the age group of 21-24.

\section{Sampling}

In this study, accessible and targeted sampling was used. News group of 12 universities were communicated in order to access university students in Turkey. Moreover, an announcement for academic research was made to various social media accounts of universities. It is known that such kinds of samplings compose certain restrictions in the sense of external validity of results, yet 
students who represented 36 different universities in Turkey within the scope of the present study give an idea about representation of population.

Table 1. Distribution of Participants According to Faculties and Classes

\begin{tabular}{|c|c|c|c|c|c|c|}
\hline & $\begin{array}{l}\text { Faculty of } \\
\text { Education }\end{array}$ & $\begin{array}{c}\text { Faculty of } \\
\text { Economics and } \\
\text { Administrative } \\
\text { Sciences }\end{array}$ & $\begin{array}{l}\text { Faculty of Arts and } \\
\text { Sciences }\end{array}$ & $\begin{array}{c}\text { Faculty of } \\
\text { Engineering and } \\
\text { Architecture }\end{array}$ & $\begin{array}{c}\text { Faculty of } \\
\text { Medicine and } \\
\text { Health Sciences }\end{array}$ & Total \\
\hline $\begin{array}{l}\text { Preparatory } \\
\text { Student }\end{array}$ & 2 & 2 & 0 & 0 & 2 & 6 \\
\hline Freshman & 12 & 1 & 4 & 3 & 2 & 22 \\
\hline Sophomore & 20 & 3 & 5 & 4 & 2 & 34 \\
\hline Junior & 23 & 9 & 5 & 27 & 5 & 69 \\
\hline Senior & 14 & 12 & 8 & 35 & 0 & 69 \\
\hline Graduate & 5 & 3 & 1 & 3 & 9 & 21 \\
\hline $\begin{array}{l}\text { Total (N) (girls, } \\
\text { boys) }\end{array}$ & $76(47,29)$ & $30(17,13)$ & $23(13,10)$ & $72(40,32)$ & $20(14,6)$ & $\begin{array}{c}221 \\
(131, \\
90)\end{array}$ \\
\hline
\end{tabular}

\section{Questionnaire}

A questionnaire has been developed as data gathering tool for the specific purpose of this study. This questionnaire integrating university students has collected information on printed book reading habits, e-book reading habits (methods of obtain, aim of usage etc.) and technological knowledge (e-book related tools and file formats etc.) as well as demographic information of students with 14 questions (including demographic information). The questionnaire has been presented online to the attention of university students in Turkey. A particular portion of questionnaire has been distributed in printed format. When used in suitable ways and through good sampling, online surveys are more advantageous over other types of survey because of targeted sample and filling the questionnaire by voluntaries (Evans \& Mathur, 2005). However, it is more appropriate when the number of question does not exceed 15 (Resnick, 2012).

Related literature was analyzed for content analysis of the survey (University of Liverpool e-Book Study, 2010). Moreover, 5 university students were interviewed through survey questions (The questionnaire was piloted with 5 students for its clarity and wording), and based on the information obtained survey questions were rearranged. Views of 2 experts were also taken for face and content validity of the questionnaire.

\section{Procedures}

The university students, who were reached by news groups and relevant social networks, were requested to complete the 10 minute-long questionnaire. In the introduction sentence, the volunteering participants were informed briefly on the purpose of the study and the fact that the 
information to be obtained would only be used for the stated purpose of the study. The questionnaire was left open and accessible in the system for 2 weeks period and those who filled in the questionnaire completely within this period were taken into account. The data, gathered online and hardcopy, were merged afterwards.

\section{Findings}

Research findings have been analyzed under 3 major headlines: book reading habits, e-book reading habits and the most frequently used e-book medium and file formats.

\section{(1) Book Reading Habits with Respect to Faculties}

(a) With respect to faculties what is the distribution of book types read by university students?

Table 2. Book Types by Faculties

\begin{tabular}{|c|c|c|c|c|c|c|}
\hline & $\begin{array}{l}\text { Faculty of } \\
\text { Education }\end{array}$ & $\begin{array}{c}\text { Faculty of } \\
\text { Economics and } \\
\text { Administrative } \\
\text { Sciences }\end{array}$ & $\begin{array}{l}\text { Faculty of Arts } \\
\text { and Sciences }\end{array}$ & $\begin{array}{l}\text { Faculty of } \\
\text { Engineering and } \\
\text { Architecture }\end{array}$ & $\begin{array}{c}\text { Faculty of } \\
\text { Medicine and } \\
\text { Health Sciences }\end{array}$ & Total \\
\hline Novel-Story & $85,5 \%$ & $96,7 \%$ & $78,3 \%$ & $88,9 \%$ & $85,0 \%$ & $87,3 \%$ \\
\hline $\begin{array}{l}\text { Psychology- } \\
\text { Philosophy }\end{array}$ & $39,5 \%$ & $26,7 \%$ & $73,9 \%$ & $34,7 \%$ & $50,0 \%$ & $40,7 \%$ \\
\hline Article-Essay & $40,8 \%$ & $36,7 \%$ & $52,2 \%$ & $36,1 \%$ & $60,0 \%$ & $41,6 \%$ \\
\hline Poem-Memoir & $34,2 \%$ & $30,0 \%$ & $47,8 \%$ & $18,1 \%$ & $45,0 \%$ & $30,8 \%$ \\
\hline Course book & $46,1 \%$ & $56,7 \%$ & $69,6 \%$ & $40,3 \%$ & $65,0 \%$ & $49,8 \%$ \\
\hline I don't read book & $5,3 \%$ & $3,3 \%$ & $0,0 \%$ & $6,9 \%$ & $0,0 \%$ & $4,5 \%$ \\
\hline Total (N) & 76 & 30 & 23 & 72 & 20 & 221 \\
\hline
\end{tabular}

Table 2 manifests that the university students read mostly Novel-Story types of books. This ratio is the highest amongst the students in Faculty of Economics and Administrative Sciences with a ratio of $97 \%$. The type of book which is read the least among university students is Poem-Memoir with the rate of $31 \%$. Books of psychology-philosophy are read most commonly by students of Faculty of Arts and Sciences with the rate of $74 \%$; then by students of Faculty of Economics and Administrative Sciences with the rate of $27 \%$. While article-essay type is most commonly read by students of Faculty of Medicine and Health Sciences, they are least commonly read by students of Faculty of Engineering and Architecture (36\%). Poem-Memoir type which is the least preferred type of book among the participating university students is most commonly read by students of Faculty of Arts and Sciences with the rate of $48 \%$. This type is least commonly preferred by students of Faculty of Engineering and Architecture (18\%). Novel-story type is most commonly preferred among students which are followed by course book. This type is mostly preferred by students of Faculty of Arts and Sciences. Course book is least commonly read by students of 
Faculty of Engineering and Architecture (40\%). "I read no books" is the least frequently selected option. There has been no single student from Faculty of Arts and Sciences and Faculty of Medicine and Health Sciences that stated to read no books ever.

(b) What is the distribution of book reading frequency amongst university students with respect to faculties?

Table 3. Frequency of Reading Book by Faculties

\begin{tabular}{|c|c|c|c|c|c|c|}
\hline & $\begin{array}{l}\text { Faculty of } \\
\text { Education }\end{array}$ & $\begin{array}{c}\text { Faculty of } \\
\text { Economics and } \\
\text { Administrative } \\
\text { Sciences }\end{array}$ & $\begin{array}{l}\text { Faculty of Arts } \\
\text { and Sciences }\end{array}$ & $\begin{array}{c}\text { Faculty of } \\
\text { Engineering } \\
\text { and } \\
\text { Architecture }\end{array}$ & $\begin{array}{c}\text { Faculty of } \\
\text { Medicine and } \\
\text { Health Sciences }\end{array}$ & Total \\
\hline In a week & $60,5 \%$ & $73,3 \%$ & $78,3 \%$ & $73,6 \%$ & $60,0 \%$ & $68,3 \%$ \\
\hline In a month & $26,3 \%$ & $16,7 \%$ & $13,0 \%$ & $12,5 \%$ & $35,0 \%$ & $19,9 \%$ \\
\hline In 6 months & $10,5 \%$ & $6,7 \%$ & $4,3 \%$ & $8,3 \%$ & $0,0 \%$ & $7,7 \%$ \\
\hline In a year & $2,6 \%$ & $0,0 \%$ & $4,3 \%$ & $4,2 \%$ & $0,0 \%$ & $2,7 \%$ \\
\hline $\begin{array}{l}\text { Longer than a } \\
\text { year }\end{array}$ & $0,0 \%$ & $3,3 \%$ & $0,0 \%$ & $1,4 \%$ & $5,0 \%$ & $1,4 \%$ \\
\hline Total (N) & 76 & 30 & 23 & 72 & 20 & 221 \\
\hline
\end{tabular}

When Table 3 is analyzed, it is observed that $68 \%$ of university students read one book in a week. This ratio is the highest amongst the students in Faculty of Arts and Sciences with a ratio of $78 \%$. The students from Faculty of Medicine and Health Sciences have been the least frequent book readers who selected the option "longer than a year" with a ratio of $5 \%$. When the answers of "in a week" and "in a month" are regarded together as "at least once a month"; it is seen that $88 \%$ of students read at least one book in a month. In the same evaluation it is observed that students of Faculty of Medicine and Health Sciences read at least one book with the highest rate (95\%) and this is followed by students of Faculty of Education with the rate of $87 \%$. Students of Education Faculty have the highest rate (11\%) with the statement of having read book "in the last 6 months".

\section{(c) Is there a significant correlation between book reading frequency of university students and book reading habits of their social environment?}

According to Table 4, there is a significant correlation between book reading frequency of university students and book reading habits of their social environment. Students who gave the answer of "once a week" for reading frequency in Table 4; replied to the question who has the highest rate of reading habit in social environment as their mother with $30 \%$, father with $16 \%$, friends with $11 \%$, siblings with $8 \%$ and finally teacher with $4 \%$. According to this result, students who have the highest rate of reading habit with "once a week" stated that the person who reads most is their mother. These results can be analyzed in more details in further studies that investigate factors which determine reading habits of students. 
Table 4. Correlation between Social Environment and Book Reading Frequency

\begin{tabular}{|c|c|c|c|c|c|c|c|c|c|c|c|c|}
\hline \multirow{3}{*}{$\begin{array}{l}\text { Frequency of } \\
\text { reading book }\end{array}$} & \multicolumn{12}{|c|}{ Most people around me who reads books } \\
\hline & \multicolumn{2}{|c|}{ Mother } & \multicolumn{2}{|c|}{ Father } & \multicolumn{2}{|c|}{ Sister/Brother } & \multicolumn{2}{|c|}{ Friend } & \multicolumn{2}{|c|}{ Teacher } & \multicolumn{2}{|c|}{ Total } \\
\hline & $f$ & $\%$ & $f$ & $\%$ & $f$ & $\%$ & $f$ & $\%$ & $f$ & $\%$ & $f$ & $\%$ \\
\hline In a week & 66 & 29,7 & 35 & 15,8 & 17 & 7,7 & 24 & 10,8 & 9 & 4,1 & 151 & 68,0 \\
\hline In a month & 15 & 6,8 & 6 & 2,7 & 6 & 2,7 & 8 & 3,6 & 9 & 4,1 & 44 & 19,8 \\
\hline In 6 months & 5 & 2,3 & 5 & 2,3 & 3 & 1,4 & 0 & 0,0 & 4 & 1,8 & 17 & 7,7 \\
\hline In a year & 4 & 1,8 & 3 & 1,4 & 0 & 0,0 & 0 & 0,0 & 0 & 0,0 & 7 & 3,2 \\
\hline $\begin{array}{l}\text { Longer than a } \\
\text { year }\end{array}$ & 1 & 0,5 & 0 & 0,0 & 1 & 0,5 & 1 & 0,5 & 0 & 0,0 & 3 & 1,4 \\
\hline Total & 91 & 41,0 & 49 & 22,1 & 27 & 12,2 & 33 & 14,9 & 22 & 9,9 & 222 & 100 \\
\hline
\end{tabular}

$X^{2}=21,51 ; s d=16 ; p<.05$

\section{(2) E-Book Reading Habits with Respect to Faculties}

\section{(a) With respect to faculties what is the distribution of e-book reading habits amongst the university students?}

Table 5. E-book Reading Habits by Faculties

\begin{tabular}{|l|c|c|c|c|c|c|}
\hline & $\begin{array}{c}\text { Faculty of } \\
\text { Education }\end{array}$ & $\begin{array}{c}\text { Faculty of } \\
\text { Economics and } \\
\text { Administrative } \\
\text { Sciences }\end{array}$ & $\begin{array}{c}\text { Faculty of } \\
\text { Arts and } \\
\text { Sciences }\end{array}$ & $\begin{array}{c}\text { Faculty of } \\
\text { Engineering } \\
\text { and } \\
\text { Architecture }\end{array}$ & $\begin{array}{c}\text { Faculty of } \\
\text { Medicine and } \\
\text { Health Sciences }\end{array}$ & \multicolumn{1}{|c|}{ Total } \\
\hline I read e-book & $61,8 \%$ & $69,6 \%$ & $52,2 \%$ & $70,83 \%$ & $60,0 \%$ & $62,4 \%$ \\
\hline I don't read e-book & $38,2 \%$ & $30,4 \%$ & $47,8 \%$ & $29,17 \%$ & $40,0 \%$ & $37,6 \%$ \\
\hline Total (N) & 76 & 30 & 23 & 72 & 20 & 221 \\
\hline
\end{tabular}

The findings presented in Table 5 reveal that $62 \%$ of university students are e-book readers, which is a substantial ratio indicating the prevalence of e-book technology. When distributions are analyzed on the basis of faculties, it was observed that students of Faculty of Engineering and Architecture read e-books with the highest rate (71\%) and students of Faculty of Arts and Sciences read e-books with the lowest rate (52\%).

\section{(b) What is the distribution of e-book reading objectives amongst university students with respect to faculties?}

As illustrated in Table 6, university students read e-books with a ratio of $81 \%$ mostly for research objectives. On the basis of faculties, in the Faculty of Economics and Administrative Sciences this ratio goes as high as $94 \%$. It is observed that students of Faculty of Medicine and Health Sciences (83\%) and Faculty of Engineering and Architecture (75\%) read e-books mostly "to work on a 
course material". On the other hand, it was determined that students of Faculty of Education, Faculty of Economics and Administrative Sciences and Faculty of Arts and Sciences read e-books mostly for the aim of research.

Table 6. Purpose of e-book Reading by Faculties

\begin{tabular}{|l|c|c|c|c|c|c|}
\hline & Faculty of & $\begin{array}{c}\text { Faculty of } \\
\text { Economics and } \\
\text { Administrative } \\
\text { Sciences }\end{array}$ & $\begin{array}{c}\text { Faculty of } \\
\text { Arts and } \\
\text { Sciences }\end{array}$ & $\begin{array}{c}\text { Faculty of } \\
\text { Engineering and } \\
\text { Architecture }\end{array}$ & $\begin{array}{c}\text { Faculty of } \\
\text { Medicine and } \\
\text { Health Sciences }\end{array}$ & Total \\
\hline $\begin{array}{l}\text { To work on course } \\
\text { material }\end{array}$ & $74,5 \%$ & $75,0 \%$ & $66,7 \%$ & $74,5 \%$ & $83,3 \%$ & $74,6 \%$ \\
\hline Research read & $89,4 \%$ & $93,8 \%$ & $83,3 \%$ & $70,6 \%$ & $75,0 \%$ & $81,2 \%$ \\
\hline $\begin{array}{l}\text { To } \\
\text { story/novel/poetry } \\
\text { books }\end{array}$ & $42,6 \%$ & $43,8 \%$ & $41,7 \%$ & $29,4 \%$ & $16,7 \%$ & $35,5 \%$ \\
\hline Total $(\mathrm{N})$ & 47 & 16 & 12 & 51 & 12 & $\mathrm{~N}=138$ \\
\hline
\end{tabular}

The least use of e-book among university students is for reading story-novel-poetry books (36\%). When analyzed according to faculties, it was found that students of Faculty of Medicine and Health Sciences (17\%) read electronic story-novel-poetry type with the least frequency as e-book and Faculty of Economic and Administrative Sciences (44\%) has the highest rate of reading e-book for this aim.

\section{(c) What is the distribution of e-book search formats amongst university students with respect to faculties?}

Table 7. Accessing e-Books by Faculties

\begin{tabular}{|l|c|c|c|c|c|c|}
\hline & $\begin{array}{c}\text { Faculty of } \\
\text { Education }\end{array}$ & $\begin{array}{c}\text { Faculty of } \\
\text { Economics and } \\
\text { Administrative } \\
\text { Sciences }\end{array}$ & $\begin{array}{c}\text { Faculty of } \\
\text { Arts and } \\
\text { Sciences }\end{array}$ & $\begin{array}{c}\text { Faculty of } \\
\text { Engineering } \\
\text { and } \\
\text { Architecture }\end{array}$ & $\begin{array}{c}\text { Faculty of } \\
\text { Medicine and } \\
\text { Health Sciences }\end{array}$ & Total \\
\hline University library & $38,3 \%$ & $31,2 \%$ & $50,0 \%$ & $31,4 \%$ & $8,3 \%$ & $33,3 \%$ \\
\hline $\begin{array}{l}\text { Internet search } \\
\text { engine (Google } \\
\text { books etc.) }\end{array}$ & $66,0 \%$ & $62,5 \%$ & $58,3 \%$ & $66,7 \%$ & $75,0 \%$ & $65,9 \%$ \\
\hline $\begin{array}{l}\text { Publishers own } \\
\text { sites }\end{array}$ & $23,4 \%$ & $18,8 \%$ & $41,7 \%$ & $19,6 \%$ & $8,3 \%$ & $21,7 \%$ \\
\hline Social media & $12,8 \%$ & $18,8 \%$ & $25,0 \%$ & $9,8 \%$ & $8,3 \%$ & $13,0 \%$ \\
\hline Total (N) & 47 & 16 & 12 & 51 & 12 & $\mathrm{~N}=138$ \\
\hline
\end{tabular}

Table 7 unravels that access to e-book is achieved 66\% through search engines. With respect to faculties this ratio is the highest amongst the students in Faculty of Medicine and Health Sciences with a ratio of $75 \%$. University libraries have the $2^{\text {nd }}$ rank for e-book search among university students (33\%). When students who search e-book by using university libraries are compared in relation to faculties, students of Faculty of Arts and Science have the highest rate with $50 \%$. It was 
determined that it is the students of Faculty of Medicine and Health Sciences (22\%) who use university library for this aim least frequently $(8 \%)$. Publishers own sites have the $3^{\text {rd }}$ rank $(22 \%)$ for e-book search among university students. It was determined that this style is preferred most by students of Faculty of Arts and Sciences (42\%) and least preferred by students of Faculty of Medicine and Health Sciences with the rate of $8 \%$. It has also been uncovered that the least frequently used method in e-book search is social media with a ratio of $13 \%$.

\section{(d) What is the distribution of e-book reading formats amongst university students with respect to faculties?}

Table 8 shows that with a ratio of $74 \%$ e-book is mostly downloaded from its original source. Students from Faculty of Arts and Sciences are the most frequent downloaders with a ratio of $92 \%$. The least preferred method is online reading with a ratio of $25 \%$. It is not actually plausible to name the downloaded then printed book as e-book reading yet there is a substantial high level of students ( $28 \%$ ) favoring such reading format.

Table 8. Types of Reading e-Books by Faculties

\begin{tabular}{|l|c|c|c|c|c|c|}
\hline & $\begin{array}{c}\text { Faculty of } \\
\text { Education }\end{array}$ & $\begin{array}{c}\text { Faculty of } \\
\text { Economics and } \\
\text { Administrative } \\
\text { Sciences }\end{array}$ & $\begin{array}{c}\text { Faculty of } \\
\text { Arts and } \\
\text { Sciences }\end{array}$ & $\begin{array}{c}\text { Faculty of } \\
\text { Engineering } \\
\text { and } \\
\text { Architecture }\end{array}$ & $\begin{array}{c}\text { Faculty of } \\
\text { Medicine and } \\
\text { Health Sciences }\end{array}$ & Total \\
\hline Online reading & $31,9 \%$ & $18,8 \%$ & $25,0 \%$ & $19,6 \%$ & $25,0 \%$ & $24,6 \%$ \\
\hline $\begin{array}{l}\text { Download and } \\
\text { screen reading }\end{array}$ & $80,9 \%$ & $50,0 \%$ & $91,7 \%$ & $72,5 \%$ & $66,7 \%$ & $73,9 \%$ \\
\hline $\begin{array}{l}\text { Download and } \\
\text { print out }\end{array}$ & $27,7 \%$ & $18,8 \%$ & $25,0 \%$ & $33,3 \%$ & $16,7 \%$ & $27,5 \%$ \\
\hline Total (N) & 47 & 16 & 12 & 51 & 12 & $\mathrm{~N}=138$ \\
\hline
\end{tabular}

Within the scope of survey, choice of download and print out was included within e-book reading types. In this way it was aimed to determine students who state they read e-book but in fact accessed resource electronically as they preferred reading in printed format. Therefore, it can be said that $28 \%$ of students who state that they read e-book have misperception about e-book reading.

\section{(e) What aspects do university students deem to be advantageous in e-books over} printed resources?

Research findings have manifested that the biggest advantage of e-book over printed resources is easy access (68\%). The second important advantage of e-book is ease of archive (58\%). The ratio of students who claim to have detected no advantage has been as low as $7 \%$. With respect to faculties, students from Faculty of Education (68\%), Faculty of Economics and Administrative Sciences(63\%), Faculty of Engineering and Architecture (77\%) have stated the biggest advantage of e-book as its easy access while students from Faculty of Arts and Sciences and Faculty of Medicine 
and Health Sciences pointed to the easy archiving. Advantages of Ease of archive, ease of use, ease of read and up to dateness were emphasized mostly by students of Faculty of Arts and Sciences with the rates of $75 \%, 50 \%, 42 \%, 42 \%$ respectively The advantage of ease of access is mostly emphasized by students of Faculty of Engineering and Architecture (77\%). According to Table 9, properties of ease of archive (50\%), ease of use (13\%), ease of read (13\%) and up to dateness (6\%) are the least frequently emphasized as advantage by students of Faculty of Economics and Administrative Sciences.

Table 9. Advantages of e-books by Faculties

\begin{tabular}{|l|c|c|c|c|c|c|}
\hline & $\begin{array}{c}\text { Faculty of } \\
\text { Education }\end{array}$ & $\begin{array}{c}\text { Faculty of } \\
\text { Economics and } \\
\text { Administrative } \\
\text { Sciences }\end{array}$ & $\begin{array}{c}\text { Faculty of } \\
\text { Arts and } \\
\text { Sciences }\end{array}$ & $\begin{array}{c}\text { Faculty of } \\
\text { Engineering and } \\
\text { Architecture }\end{array}$ & $\begin{array}{c}\text { Faculty of } \\
\text { Medicine and } \\
\text { Health Sciences }\end{array}$ & Total \\
\hline Ease of access & $68,1 \%$ & $62,5 \%$ & $58,3 \%$ & $76,5 \%$ & $50,0 \%$ & $68,1 \%$ \\
\hline Ease archive & $57,4 \%$ & $50,0 \%$ & $75,0 \%$ & $56,9 \%$ & $58,3 \%$ & $58,0 \%$ \\
\hline Ease of use & $48,9 \%$ & $12,5 \%$ & $50,0 \%$ & $19,6 \%$ & $16,7 \%$ & $31,2 \%$ \\
\hline Ease of read & $38,3 \%$ & $12,5 \%$ & $41,7 \%$ & $39,2 \%$ & $25,0 \%$ & $34,8 \%$ \\
\hline Up to dateness & $25,5 \%$ & $6,2 \%$ & $41,7 \%$ & $9,8 \%$ & $25,0 \%$ & $18,8 \%$ \\
\hline No advantage & $4,3 \%$ & $0,0 \%$ & $25,0 \%$ & $2,0 \%$ & $25,0 \%$ & $6,5 \%$ \\
\hline Total (N) & 47 & 16 & 12 & 51 & & 12 \\
\hline
\end{tabular}

\section{(3) The Most Frequently Used e-Book Medium and File Formats}

\section{a) What is the distribution of e-book medium and file formats used frequently amongst university students?}

As shown in the Table 10, amongst university students the most frequently used file format has been Portable Document Format (.pdf) with a ratio of $73 \%$ and the least frequently used format has been found to be Kindle (.azw). According to Table 11, the most frequently used e-book medium has been computer with a ratio of $60 \%$ and the least frequently used medium has been epad and PDA with a ratio of $4 \%$.

Table 10. Usages of e-Book File Types

\begin{tabular}{|c|c|c|c|c|c|c|c|c|c|c|c|}
\hline \multicolumn{2}{|c|}{$\begin{array}{l}\text { Portable } \\
\text { Document } \\
\text { Format } \\
\text { ".pdf " }\end{array}$} & \multicolumn{2}{|c|}{$\begin{array}{l}\text { Plain text files } \\
\text { ".txt" }\end{array}$} & \multicolumn{2}{|c|}{ EPUB (IDPF) "epub } & \multicolumn{2}{|c|}{ Kindle ".azw " } & \multicolumn{2}{|c|}{$\begin{array}{c}\text { Microsoft Reader } \\
\text { ".lit " }\end{array}$} & \multicolumn{2}{|c|}{ E-Reader } \\
\hline$f$ & $\%$ & $f$ & $\%$ & $f$ & $\%$ & $f$ & $\%$ & $f$ & $\%$ & $f$ & $\%$ \\
\hline 100 & 73 & 39 & 28 & 5 & 4 & 4 & 3 & 17 & 12 & 19 & 14 \\
\hline \multicolumn{2}{|c|}{ Total } & & & & & & & & & \multicolumn{2}{|c|}{138} \\
\hline
\end{tabular}


Table 11. Usage of E-book Medium

\begin{tabular}{|c|c|c|c|c|c|c|c|c|c|c|c|c|c|}
\hline \multicolumn{2}{|c|}{ E-Reader } & \multicolumn{2}{|c|}{ PDA } & \multicolumn{2}{|c|}{ Smart Phone } & \multicolumn{2}{|c|}{ Cell Phone } & \multicolumn{2}{|c|}{$\begin{array}{c}\text { Tablet } \\
\text { Computer }\end{array}$} & \multicolumn{2}{|c|}{ E-Pad } & \multicolumn{2}{|c|}{ Computer } \\
\hline$f$ & $\%$ & $f$ & $\%$ & $f$ & $\%$ & $f$ & $\%$ & $f$ & $\%$ & $f$ & $\%$ & $f$ & $\%$ \\
\hline 19 & 14 & 5 & 4 & 24 & 17 & 26 & 19 & 16 & 12 & 6 & 4 & 83 & 60 \\
\hline \multicolumn{3}{|c|}{ Total } & & & & & & & & & & \multicolumn{2}{|c|}{138} \\
\hline
\end{tabular}

\section{Conclusion}

According to research findings $62 \%$ of university students state that they use e-book. Parallel to this detection, an earlier research conducted in 2009 showed that students preferred e-book with a ratio of $11 \%$, printed resources with a ratio of $26 \%$ and both resources with a ratio of $56 \%$ (Shelburne, 2009). In another research conducted 3 years afterwards in 2011 (Zhang \& Backman, 2011) it has been designated that amongst university students the ratio of electronic resource users is $53 \%$ while the ratio of printed resource users is $47 \%$.

Again according to the findings of study, students read mostly (87\%) novels etc. as printed books and as e-books they place research books (87\%) to the first rank and course materials to the second rank (75\%). This finding may be bound to the fact that a vast majority of e-book format books are research or course texts. The fact that students deem easy access of e-book as its biggest advantage is also supportive of the prevalence of e-book format research books. It can further be asserted that the fact that course materials are more accessible in electronic environment is also an influential factor. Shelburne's research in 2009 has similarly echoed the finding that students deem easy access of e-book as its greatest advantage. Although it is contradictory that students mostly read novel type yet the aim of reading e-book is to make research and read course material; this case can be explained with restricted e-book resource in novel-story type. Therefore publishers should consider the publishing of e-book as a requirement in this field.

It is the students of Faculty of Arts and Science who read books most frequently; however, e-book reading is least frequently preferred by the students of this faculty. Reasons of this situation can be analyzed in further studies.

When students who state reading e-book were asked how they read e-book, $28 \%$ of students marked the choice of download and print out. This result shows that there is a misconception about e-book. It is quite important to consider this issue in further studies to be carried out on ebook.

Another salient finding underlines that students have regular book reader parents which draws attention to the fact that a great majority of students have failed to identify their friends as the regular book readers. From the perspective of social learning, it is acknowledged that students spend most of their times with friends and learn through mutual interaction with each other. 
Taking this finding into consideration, the book reading habits of students' role-models and the factors influential on their book reading frequencies stands before us as a topic that deserves further analysis. Aside from all above mentioned factors, in comparative analyses with respect to faculties the quantity of e-book resources in different domains should also be taken into account. It is no surprise that use of e-book is scarce in any subject with limited electronic resources. It would be even further beneficial if comparison of faculties' findings of present research is evaluated with respect to accessible e-book resources on subject area.

When the difference between faculties regarding the usage of e-book is analyzed in relation to the results of the study, it can be seen that the students of the Engineering Faculty have the highest ratio of e-book reading. This result is also consistent with the studies in the literature (Christianson, 2005; Slater, 2009; Sprague \& Hunter, 2009), which determines the order of the most popular e-book topics as computers, technology, and specific sciences. Depending on these findings, it can be said that e-book resource in specific fields largely determines the rate of e-book literacy. This finding implies that there is a need or requirement for e-book publishing in other fields as well.

Considering the increase of e-book literacy, it is observed that recently published books should have an electronic format and the books in hard-copy format should be transformed into e-book format. Moreover, when it is considered that making research and reading course materials are the most important purposes for students reading e-book, it is clear that it has become necessary for academicians to present lecture notes and resources in electronic format.

\section{References}

Annand, D. (2008). Learning efficacy and cost-effectiveness of print versus e-book instructional material in an introductory financial accounting course. Journal of Interactive Online Learning, 7(2), 152-164.

Armstrong, C.J., Edwards, L., \& Lonsdale, R. (2002). Virtually there? E-books in UK academic libraries. Program: Electronic Library and Information Systems, 36(4), 216-27.

Cassidy, E. D., Martinez, M., \& Shen, L. ( 2012). Not in love, or not in the know? Graduate student and faculty use (and non-use) of e-books. The Journal of Academic Librarianship, 38(6), 326332.

Christianson, M. (2005). Patterns of use of electronic books. Library Collections, Acquisitions, \& Technical Services, 29, 351-363.

Evans, J. R. \& Mathur, A. (2005). The value of online surveys. Internet Research, 15(2), 195-219.

İsmail, R. \& Zainab, A. N. (2005). The pattern of e-book use amongst undergraduates in Malaysia: A case of to know is to use. Malaysian Journal of Library \& Information Science, 10(2), 1-23.

Letchumanan, M. \& Tarmizi, R. A. Utilization of e-book among university mathematics students. (2010). Procedia Social and Behavioral Sciences, 8, 580-587.

Mischo, W. H., Norman, M. A., Shelburne, W. A., \& Schlembach, M. C. (2007). The growth of electronic journals in libraries. Science \& Technology Libraries, 26(3/4), 29-59. 
Muir, L. \& Hawes, G. (2013). The case for e-book literacy: Undergraduate students' experience with e-books for course work. The Journal of Academic Librarianship (Articles in press). Available at: dx.doi.org/10.1016/j.acalib/2013.01.002

Nicholas, D., Rowlands, I., Clark, D., Huntington, P., Jamali, H. R., \& Olle, C. (2008). UK scholarly ebook usage: A landmark survey. Aslib Proceedings: New Information Perspectives, 60(4), 311-334.

Ntvmsnbc (2012). E-kitap kâğıdı geçti. Retrieved 25 August 2012 from http://www.ntvmsnbc.com/ id/25372204.

Resnick, R. M. (2012). Comparison of postal and online surveys: Cost, speed, response rates and reliability. Education Market Research and MCH Strategic Data. Available at: https:// f6495f0e992a958132f3bbdab404e70f099b18ec72f5a527f500.ssl.cf1.rackcdn.com/cms/wpcontent/uploads/2012/10/Comparison_of_Postal_and_Online_Surveys.pdf

Rosso, S. (2009). What are ebooks? Advantages and disadvantages of electronic books. Retrieved on 5 March 2012 from http://whenihavetime.com/2009/03/09/what-are-ebooksadvantages-and-disadvantages-of-electronic-books/\#advantages.

Shelburne, W. A. (2009). E-book usage in an academic library: User attitudes and behaviors. Library Collections, Acquisitions, \& Technical Services, 33, 59-72.

Slater, R (2009). E-books or print books, "big deals" or local selections-What gets more use?, Library Collections, Acquisitions, \& Technical Services, 33, 31-41.

Sprague, N. \& Hunter, B (2009). Assessing e-books: Taking a closer look at e-book statistics. Library Collections, Acquisitions, \& Technical Services, 32, 150-157.

Szapkiw, A. J. R., Courduff, J. C., Carter, K., \& Bennett, D. (2013). Electronic versus traditional print textbooks: A comparison study on the influence of university students' learning Computers \& Education, 63, 259-266.

University of Liverpool eBook Study (2010). A Survey of eBook usage and perceptions at the University of Liverpool (White Paper). Available at: http://www.springer.com/cda/ content/document/cda_downloaddocument/V7671+Liverpool+White+Paper+Part2.pdf?SG WID $=0-0-45-1037538-0$

Vasileiou, M., Rowley, J., \& Hartley, R., (2012). The e-book management framework: The management of e-books in academic libraries and its challenges. Library \& Information Science Research, 34, 282-291.

Woody, W. D., Daniel, D. B., \& Baker, C. A. (2010). E-books or textbooks: Students prefer textbooks. Computers \& Education, 55, 945-948.

Zhang, Y. \& Beckman, R. (2011). E-book usage among chemists, biochemists and biologists: Findings of a survey and interviews. Issues in Science and Technology Librarianship, 65. Available at: http://www.istl.org/11-spring/article2.html 
Correspondence: Gonca Kizilkaya Cumaoglu, Assistant Professor, Department of Computer Education and Instructional Technologies, Yeditepe University, 26 Agustos Yerlesimi, Atasehir, Istanbul, Turkey 